\title{
The Effectiveness of Problem Based Learning-Based Interactive Multimedia for Elementary School Students
}

\section{Tunjung Sekarwangi ${ }^{*}$, Kus Eddy Sartono², Ali Mustadi ${ }^{3}$, Abdulah $^{4}$}

1,2,3,4 Pendidikan Dasar, Fakultas Ilmu Pendidikan, Universitas Negeri Yogyakarta, Yogyakarta, Indonesia

\section{ART I CLE IN F O}

\section{Article history}

Received January 28, 2021

Revised January 30, 2021

Accepted May 11, 2021

Available online May 25, 2021

Kata Kunci:

Multimedia Interaktif,

Pembelajaran Berbasis Masalah

Keywords:

Interactive Multimedia, Problem Based Learning

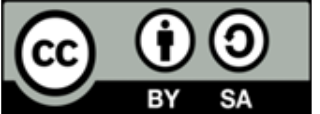

This is an open access article under the CC BY-SA license.

Copyright (@) 2021 by Author. Published by Universitas Pendidikan Ganesha.

\begin{abstract}
A B S T R A K
Kegiatan pembelajaran yang dilaksanakan secara daring memiliki beberapa kekurangan. Dalam kegiatan pembelajaran daring, guru mengalami kendala melaksanakan kegiatan pembelajaran. Kendala tersebut diantaranya adalah kurangnya media yang tepat untuk digunakan dalam kegiatan pembelajaran. Permasalahan yang terjadi menunjukkan bahwa dalam kegiatan pembelajaran siswa kesulitan dalam memahami materi pembelajaran dan motivasi belajar masih rendah. Oleh sebab itu dalam kegiatan pembelajaran, guru harus menyiapkan pembelajaran yang berkualitas. Salah satu upaya yang dapat dilakukan untuk mengatasi permasalahan tersebut adalah melalui penggunaan media pembelajaran yang tepat. Sehingga dapat meningkatkan proses dan hasil belajar yang lebih baik. Penelitian ini menggunakan pendekatan penelitian dan pengembangan (R\&D). Tujuan dari penelitian ini adalah untuk mengembangkan teknologi pembelajaran dalam bentuk multimedia interaktif berbasis problem based learning. Langkah-langkah yang digunakan dalam penelitian dan pengembangan ini adalah model pengembangan ADDIE. Data penelitian diperoleh melalui instrumen lembar validasi media oleh ahli. Analisis data dilakukan secara kuantitatif deskriptif. Hasil uji kelayakan media berdasarkan hasil validasi diperoleh nilai sebesar 80\%. Berdasarkan hasil penelitian yang telah dilakukan dapat disimpulkan bahwa multimedia interaktif berbasis problem based learning layak digunakan dalam kegiatan pembelajaran. Implikasi dari hasil penelitian ini adalah penggunaan multimdia interaktif berbasis problem based learning berperan penting terhadap efektifitas kegiatan pembelajaran.
\end{abstract}

\section{A B S T R A C T}

Learning activities carried out online have several drawbacks. In online learning activities, teachers experience problems carrying out learning activities. These obstacles include the lack of appropriate media to be used in learning activities. The problems that occur indicate that in learning activities students have difficulty in understanding learning materials and learning motivation is still low. Therefore, in learning activities, teachers must prepare quality learning. One of the efforts that can be done to overcome these problems is through the use of appropriate learning media. So that it can improve the process and better learning outcomes. This study uses a research and development (R\&D) approach. The purpose of this research is to develop learning technology in the form of interactive multimedia based on problem-based learning. The steps used in this research and development is the ADDIE development model. The research data was obtained through a media validation sheet instrument by an expert. Data analysis was carried out quantitatively descriptively. The results of the media feasibility test based on the validation results obtained a value of $80 \%$. Based on the results of the research that has been done, it can be concluded that interactive multimedia based on problem-based learning is feasible to be used in learning activities. The results of this study imply that the use of interactive multimedia based on problem-based learning plays an important role in the effectiveness of learning activities.

\section{INTRODUCTION}

The Covid-19 pandemic had an impact on various aspects of human life, including education. The Covid-19 pandemic has paralyzed general educational activities (Adedoyin \& Soykan, 2020; Kim, 2020). Learning activities during the Covid-19 pandemic must be carried out digitally (Dong et al., 2020; Srimulyani \& Hermanto, 2021). Educational activities that have been carried out classically have also been replaced with learning activities at home (Onyema, 2020; Pribowo, 2020). hanges in student learning activities that were originally carried out in schools pose challenges for teachers in carrying out learning activities that can accommodate the needs of students during learning.

Learning at home activities known as PJJ (Distance Learning) make teachers experience obstacles in carrying out learning activities (Prawiyogi et al., 2020; Simanjuntak et al., 2020). From the results of 
interviews with teachers, the difficulty in implementing PJJ is the limited learning media that can accommodate student learning needs. During the PJJ, the teacher gave more assignments using the Whatsapp Group social media. However, the use of Whatsapp Group social media is felt by the teacher to be ineffective in learning activities, students cannot understand the concept of learning like classical learning activities. Problems that occur during online learning show that teachers need to use appropriate learning strategies, for example through the use of learning media that are packaged effectively (Rahayu \& Wirza, 2020). One type of media that can be used in learning activities is interactive multimedia. Interactive multimedia is media that can combine two or more media aspects consisting of text, images, audio, video, and animation in an integrated manner and create two-way interactions, namely between students and applications/products in certain file formats (Fikri \& Madona, 2018). In interactive multimedia, students are given the freedom to study the material repeatedly and run the program as they wish. In addition, students can also determine the material that must be studied first. Interactive multimedia can act as a learning facilitator (Saripudin et al., 2018).

The results of previous research indicate that the use of multimedia in learning activities increases student interest in learning, facilitates the delivery of material more efficiently and effectively (Namiroh et al., 2018). The results of other studies show that the use of interactive multimedia affects improving student achievement and motivation (Leow \& Neo, 2014). Interactive multimedia containing various images, animations, videos, and audio as well as colorful content makes learning activities more fun (Sholihah et al., 2020). Based on the results of this study, it can be concluded that interactive multimedia can be used in learning activities. The use of interactive multimedia in learning activities makes learning more effective and efficient. Previous research has shown that the problem-based learning model assisted by multimedia effects students' critical thinking skills (Susilawati et al., 2017). In addition, similar research resulted in findings that the development of interactive multimedia based on a scientific approach was effectively used to improve student achievement (Prasetyo \& Prasojo, 2016). Based on the results of this study, it can be concluded that the development of interactive multimedia combined with the right learning model will make learning more effective, to improve student achievement.

One of the learning models that can be combined with interactive multimedia is the problembased learning model. Problem Based Learning (PBL) is a learning model that can integrate various subjects with meaningful experiences (Rillero \& Chen, 2019). roblem-based learning is an approach that presents doing problem-solving (Bayrak \& Gürses, 2020). PBL is a learning model that fits the needs of the 21st century, this model can increase the capacity for critical analysis and teamwork (Lara, 2020). The results of the preliminary study indicate that learning activities require learning media that can improve student learning activities. Learning media is needed so that students can take part in learning activities with full attention. In addition, the results of this preliminary study also show that the learning media needed in learning activities are interactive multimedia based on problem-based learning. The purpose of this research is to produce a product in the form of interactive multimedia based on problem-based learning and to test the product based on expert validation. The results of this study are expected to contribute solutions to the problems that occur and make learning more interactive, interesting, and easier for students to understand the learning material.

\section{METHOD}

This research aims to produce interactive multimedia products based on problem-based learning. This research is a type of research and development (R\&D). The research design used to produce interactive multimedia is the ADDIE development model. The procedure carried out in this research includes five stages of ADDIE interactive multimedia development. The five stages include analysis, design, development, implementation, and evaluation (Sugiyono, 2017; Tegeh \& Kirna, 2013). The subject of this research is product development in the form of interactive multimedia based on problem-based learning. The object of this research is the validity of the developed media product. The media development process involves learning material experts, media experts, and learning evaluation experts. In addition, this study also involved fifth-grade students in elementary schools located in Depok District, Sleman Regency to determine student responses to the developed media. The instrument used to collect data in this study used a media validation questionnaire by experts and a student response questionnaire to learning media. The indicators that become the points of media validation assessment are presented in Table 1. 
Table 1. Media Validation Instruments Grid

\begin{tabular}{lll}
\hline No. & Aspect & Indicators \\
\hline 1 & Learning materials & The suitability of the material with basic competencies \\
& & Ease of understanding the material \\
& & Material clarity \\
& & The suitability of the material with the learning objectives \\
2 & Media Display & Image clarity \\
& & Video clarity \\
& & Voice clarity \\
& & Ease of operating the menu \\
& & The suitability of the evaluation with the learning material \\
\hline
\end{tabular}

In addition, Table 2 presents a questionnaire grid for student responses to learning media.

Table 2. Student Response Questionnaire Instruments Grid

\begin{tabular}{lll}
\hline No. & Aspect & Indicators \\
\hline 1 & Learning materials & Ease of understanding the material \\
& & The suitability of the image with the material \\
& The suitability of the video with the material \\
& & Ease of reading text \\
& Programming & Ease of use of media \\
& & Ease of repeating material \\
& Ease of starting and ending programs \\
\hline
\end{tabular}

The research data were analyzed descriptively, both qualitatively and quantitatively. Qualitative analysis was carried out to improve the media products developed following the comments and inputs given by the experts during validation. Quantitative analysis was conducted to describe the results of the expert's assessment and the results of students' responses to the media.

\section{RESULT AND DISCUSSION}

\section{Result}

Based on the research that has been done, the results of research and development on interactive multimedia based on problem-based learning can be described. This study uses five stages including analysis, design, development, implementation, and evaluation. In the analysis stage, the researcher collects information/data which includes analysis of learning media needs and literature studies, and conducts a review of relevant research. After that, the next stage designs, in this stage the researcher determines the subject matter, determine the learning objectives to be achieved, and collects various media elements such as videos, images, text, and several other media elements from the internet, and makes media designs. Then at the development stage, researchers compile and develop products using the Macromedia Flash 8 application. Based on the results of product development that has been carried out, this interactive multimedia has several main menus, including instructions for using media, learning objectives, learning materials, material summaries, practice questions/quizzes, and media developer profiles. The main menu display of interactive multimedia based on problem-based learning is presented in Figure 1. Practice questions/quizzes are given to know how students understand the subject matter. In this exercise, students can find out the value obtained. In addition, students can also repeat the practice questions if the scores obtained are not maximized. The display of the quiz in interactive multimedia that has been developed is presented in Figure 2. After the product is developed, the next step is the product validation test. A product validation test is carried out to know the quality of the product that has been developed. The results of the product validation tests that have been carried out in this study are presented in Table 3.

Table 3. Recapitulation of Product Validation Test Results

\begin{tabular}{llll}
\hline No. & Aspect & Indicators & Score \\
\hline 1 & Learning & The suitability of the material with basic competencies & 4 \\
& materials & Ease of understanding the material & 4 \\
& & Material clarity & 4 \\
\hline
\end{tabular}




\begin{tabular}{llll}
\hline No. & Aspect & Indicators & Score \\
\hline \multirow{2}{*}{2} & The suitability of the material with the learning objectives & 4 \\
& Media & Image clarity & 4 \\
& Display & Video clarity & 4 \\
& & Voice clarity & 4 \\
& & Ease of operating the menu & 4 \\
3 & Learning & The suitability of the evaluation with the learning material & 4 \\
& & \\
\hline \multicolumn{2}{l}{ Total score } \\
\multicolumn{2}{l}{ Maximum score } \\
\multicolumn{2}{l}{ Percentage of media eligibility } & $\mathbf{3 6}$ \\
\hline
\end{tabular}

Based on the results of the validation test on the media that has been carried out, it can be obtained a value of 36 from a maximum value of 45 . The percentage of media feasibility obtained is a value of $80 \%$. So it can be concluded that the media is suitable for use in learning activities. After the product is validated, the next stage is the implementation stage, this stage aims to determine student responses to the use of media that has been developed. The implementation phase is carried out for fifthgrade elementary school students. Based on the implementation stage that has been carried out, data on student responses to the media can be obtained as shown in Table 4.

Table 4. Recapitulation of Student Responses

\begin{tabular}{llll}
\hline No. & Aspect & Indicators & Score \\
\hline 1 & Learning & Ease of understanding the material & 3 \\
& materials & The suitability of the image with the material & 3,4 \\
& & The suitability of the video with the material & 3,1 \\
& & Ease of reading text & 3,6 \\
2 & \multirow{2}{*}{ Programming } & Ease of use of media & 2,7 \\
& & Ease of repeating material & 3,3 \\
& Ease of starting and ending programs & 3 \\
\hline \multicolumn{2}{l}{ Total score } & & $\mathbf{2 2 , 1}$ \\
\hline \multicolumn{2}{l}{ Maximum score } & $\mathbf{2 8}$ \\
\hline
\end{tabular}

Based on the results of product trials in the initial field above, it can be obtained a value of 22.1 from a maximum value of 28 . The percentage of media feasibility obtained a value of $79 \%$. So it can be concluded that the media that has been developed is suitable for use in learning activities. After the product is implemented for students, the next stage is the evaluation stage. The evaluation stage is carried out to know the feasibility of the product that has been developed. The feasibility of the product in this study was reviewed from the results of product validation and the results of student responses to the product. The results of the analysis of the validation test and student responses to the product can be concluded that the interactive multimedia that has been developed is feasible to be applied in learning activities.

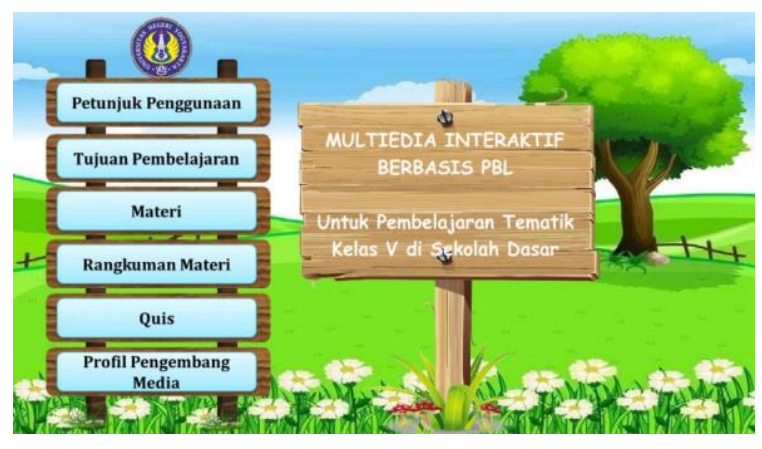

Figure 1. Main Menu Display of Interactive Multimedia Based on Problem-based learning

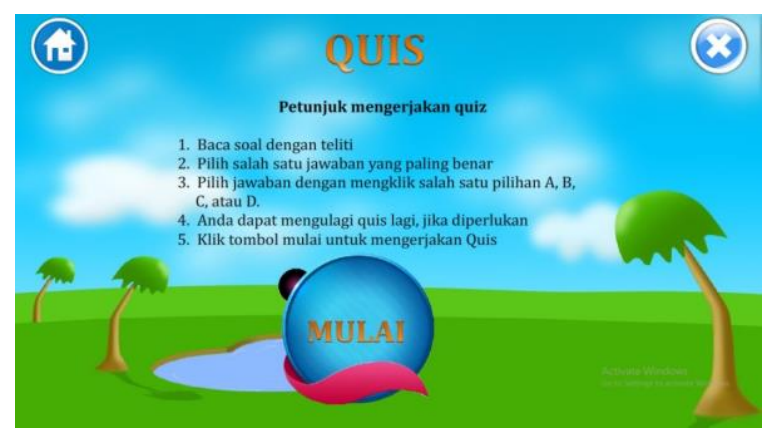

Figure 2. Main Display of Practice Questions / Quiz 


\section{Pembahasan}

Based on the results of the research above, the development of interactive multimedia based on problem-based learning is effectively applied in learning activities. This interactive multimedia can combine various media elements such as; text, images, videos, and animations. So that through the use of this media will make learning activities more attractive to students. The results of observations on the use of learning media by students showed that students were more focused on learning activities and students seemed motivated to learn. This is in line with the opinion which states that attractively packaged media can increase students' learning motivation (Ratminingsih, 2016).

The interactive multimedia developed in this study has the advantage of being able to integrate various media elements of images, text, video, and animation. With multimedia elements such as text, images, videos, animations, students have the potential to be involved and active in learning activities (Özdemir \& Öner, 2015; Widyatmojo \& Muhtadi, 2017). Multimedia integration with problem-based learning is the right thing. The use of multimedia can present various phenomena that are not easily seen by the human senses. Meanwhile, through problem-based learning students can learn to solve problems. Problem-based learning is a learning method that emphasizes student activities in learning activities and is problem-solving oriented (Balim et al., 2016). Problem-based learning can increase student activity in learning (Lapuz \& Fulgencio, 2020). Problem-based learning provides opportunities for students to develop their social skills and responsibilities (Uzun et al., 2020). Problem-based learning helps students to solve problems and improve skills in working together (Nguyen, 2020).

The development of interactive multimedia based on problem-based learning as a learning medium is very important to do. Through the development of these media can make learning activities more quality. This is because multimedia has the advantage that it can combine various media elements so as to present a more attractive appearance (Essel et al., 2016). The use of technology in the form of multimedia can motivate students to learn (Das, 2019). he use of multimedia to increase motivation is very important. This is because motivation plays an important role in learning activities. Motivation is one of the factors that can encourage students to achieve certain goals (Kanoksilapatham et al., 2021). High motivation can provide an impetus for higher learning as well (Dağgöl, 2020). Motivation plays an important role in learning activities (Saptenno et al., 2019). Motivation is the key to successful academic achievement (Partovi \& Razavi, 2019). eachers must increase students' learning motivation so that learning objectives can be achieved better (Mukni'ah, 2021).

The development of interactive multimedia based on problem-based learning in this research is equipped with learning video elements related to natural phenomena and problems that occur in everyday life. So with this element, it will make learning activities more meaningful. This is because, through these learning videos, students can more easily understand and identify how natural phenomena can occur. So that this developed multimedia can be used to overcome the limitations of the senses, space, and time to be able to observe how natural phenomena can occur. The use of learning media can clarify the presentation of information so that it can improve learning processes and outcomes, learning media can increase students' attention and learning media can be used to overcome the limitations of the senses, space, and time (Zainiyati, 2017). So that in the development of interactive multimedia based on problembased learning, it is necessary to pay attention to how to deliver the material. In order for students to be involved in learning activities, the subject matter must be delivered more attractively (Ditta et al., 2020). This is because the delivery of interesting material can affect students' motivation to learn (Kılıç, 2021). When digital media is used properly it will produce a good understanding for students (Hobbs, 2013).

\section{CONCLUSION}

The use of interactive multimedia in learning activities has an important role in the quality of learning in elementary school students. Therefore, the development of multimedia needs to be done. The results of multimedia development based on product validation tests obtained a media feasibility percentage value of $80 \%$. Then based on the results of student responses to the media, the feasibility value of $79 \%$ was obtained. So based on these results, it can be concluded that interactive multimedia based on problem-based learning that has been developed is suitable for use in learning activities.

\section{REFERENCES}

Adedoyin, O. B., \& Soykan, E. (2020). Covid-19 pandemic and online learning: the challenges and $\begin{array}{llll}\text { opportunities. Interactive Learning Environments, } 0(0), & 1-13 .\end{array}$ https://doi.org/10.1080/10494820.2020.1813180.

Balim, A. G., Inel-Ekici, D., \& Ozcan, E. (2016). Concept Cartoons Supported Problem based learning 
Method in Middle School Science Classrooms. Journal of Education and Learning, 5(2), 272. https://doi.org/10.5539/jel.v5n2p272.

Bayrak, R., \& Gürses, A. (2020). Teaching of the subject of solids through problem-based learning approach. World Journal of Education, 10(3), 47. https://doi.org/10.5430/wje.v10n3p47.

Dağgöl, G. D. (2020). Perceived academic motivation and learner empowerment levels of efl students in Turkish context. Participatory Educational Research, 7(3), 21-37. https://doi.org/10.17275/per.20.33.7.3.

Das, K. (2019). Role of ICT for better Mathematics Teaching. Shanlax International Journal of Education, 7(4), 19-28. https://doi.org/10.34293/education.v7i4.641.

Ditta, A. S., Strickland-Hughes, C. M., Cheung, C., \& Wu, R. (2020). Exposure to information increases motivation to learn more. Learning and Motivation, 72(July). https://doi.org/10.1016/j.lmot.2020.101668.

Dong, C., Cao, S., \& Li, H. (2020). Young children's online learning during COVID-19 pandemic: Chinese parents' beliefs and attitudes. Children and Youth Services Review, 118(June), 105440. https://doi.org/10.1016/j.childyouth.2020.105440.

Essel, H. B., Osei-poku, P., \& Opoku-asare, N. A. (2016). Self-Paced Interactive Multimedia Courseware: A Learning Support Resource for Enhancing Electronic Theses and Dissertations Development. Journal of Education and Practice, 7(12), 74-84.

Fikri, H., \& Madona, A. S. (2018). Pengembangan Media Pembelajaran Berbasis Multimedia Interaktif. Samudra Biru.

Hobbs, R. (2013). Improvization and strategic risk-taking in informal learning with digital media literacy. Learning, Media and Technology, 38(2), 182-197. https://doi.org/10.1080/17439884.2013.756517.

Kanoksilapatham, B., Khamkhien, A., Kitkha, P., \& Na Nongkhai, A. O. (2021). Motivation of thai university students from two disciplinary backgrounds using a hybrid questionnaire. LEARN Journal: Language Education and Acquisition Research Network, 14(1), 455-491.

Kim, J. (2020). Learning and teaching online during Covid-19: Experiences of student teachers in an early childhood education practicum. International Journal of Early Childhood, 52(2), 145-158. https://doi.org/10.1007/s13158-020-00272-6.

Kllıç, M. E. (2021). Motivation in the classroom. Participatory Educational Research (PER), 8(April), 31-56. https://doi.org/10.17275/per.21.28.8.2.

Lapuz, A. M., \& Fulgencio, M. (2020). Improving the critical thinking skills of secondary school students using problem-based learning. International Journal of Academic Multidisciplinary Research (IJAMR), 4(1), 1-7. https://files.eric.ed.gov/fulltext/ED603182.pdf.

Lara, S. O. V. (2020). Academic performance of students of urban design, applying problem-based learning (PBL). Journal of Problem Based Learning in Higher Education, 8(1), 63-71. https://doi.org/10.5278/ojs.jpblhe.v8i1.2640.

Leow, F. T., \& Neo, M. (2014). Interactive multimedia learning: Innovating classroom education in a Malaysian University. Turkish Online Journal of Educational Technology, 13(2), 99-110.

Mukni'ah. (2021). Analysis study: the ability of literation of islamic religious education students reviewed from implementing group investigation model and learning motivation. Elementary Education Online, 20(5), 59-66. https://doi.org/10.17051/ilkonline.2021.05.06.

Namiroh, S., Sumantri, M. S., \& Situmorang, R. (2018). Peran multimedia dalam pembelajaran. Prosiding Seminar Dan Diskusi Nasional Pendidikan Dasar, 352-357. http://journal.unj.ac.id/unj/index.php/psdpd/article/view/10161.

Nguyen, N.-G. (2020). Using the Problem-Based Learning in STEM Teaching About Bamboo Toothpick Houses. International Education Studies, 13(12), 70. https://doi.org/10.5539/ies.v13n12p70.

Onyema, E. M. (2020). Impact of Coronavirus Pandemic on Education. Journal of Education and Practice, 11(13), 108-121. https://doi.org/10.7176/jep/11-13-12.

Özdemir, O., \& Öner, İ. E. (2015). The Effects of Simulations and Animations on Students' Motivation in a Computer Course. Participatory Educational Research, 15(2), 53-59. https://doi.org/10.17275/per.15.spi.2.7.

Partovi, T., \& Razavi, M. R. (2019). The effect of game-based learning on academic achievement motivation of elementary school students. Learning and Motivation, 68(June). https://doi.org/10.1016/j.lmot.2019.101592.

Prasetyo, G., \& Prasojo, L. D. (2016). Pengembangan adobe flash pada pembelajaran tematik-integratif berbasis scientific approach subtema indahnya peninggalan sejarah. Jurnal Prima Edukasia, 4(1), 54. https://doi.org/10.21831/jpe.v4i1.7788.

Prawiyogi, A. G., Purwanugraha, A., Fakhry, G., \& Firmansyah, M. (2020). Efektifitas Pembelajaran Jarak 
Jauh Terhadap Pembelajaran Siswa di SDIT Cendekia Purwakarta. Jurnal Pendidikan Dasar, 11(01), 94-101.

Pribowo, F. S. P. (2020). Persepsi Guru SD Muhammadiyah Terhadap Penggunaan Gawai Dalam Pembelajaran Di Kelas. Literasi Dalam Pendidikan Di Era Digital Untuk Generasi Milenial, 209-219.

Rahayu, R. P., \& Wirza, Y. (2020). Teachers' perception of online learning during pandemic covid-19. Jurnal Penelitian Pendidikan, 20(3), 392-406. https://doi.org/10.17509/jpp.v20i3.29226.

Ratminingsih, N. M. (2016). Efektivitas media audio pembelajaran bahasa inggris berbasis lagu kreasi di kelas lima sekolah dasar. JPI (Jurnal Pendidikan Indonesia), 5(1), 27-38. https: //doi.org/10.23887/jpi-undiksha.v5i1.8292.

Rillero, P., \& Chen, Y.-C. (2019). The use of a digital problem-based learning module in science methods courses. Journal of Problem Based Learning in Higher Education, 7(1), 107-119. https: //doi.org/10.5278/ojs.jpblhe.v7i1.2349.

Saptenno, A. E., Tuaputty, H., Rumahlatu, D., \& Papilaya, P. M. (2019). The improvement of learning motivation and creative thinking skills of senior high school students through modified problem based learning model. Journal for the Education of Gifted Young Scientists, 7(4), 1175-1194. https://doi.org/10.17478/jegys.597519.

Saripudin, E., Sari, I. J., \& Mukhtar, M. (2018). Using Macro Flash Animation Media on Motion Material to Improve Learning Achievement for Learning Science in Junior High School. Jurnal Penelitian Dan Pembelajaran IPA, 4(1), 68-75. https://doi.org/10.30870/jppi.v4i1.3316.

Sholihah, A. N. N., Septiani, I., Rejekiningsih, T., Triyanto, \& Rusnaini. (2020). Development of interactive multimedia learning courseware to strengthen students' character. European Journal of Educational Research, 9(3), 1267-1279. https://doi.org/10.12973/eu-jer.9.3.1267.

Simanjuntak, S. Y., Dwimawanti, I. H., \& Hidayatullah, M. A. (2020). Respons Guru Terhadap Kebijakan Pembelajaran Jarak Jauh Selama Pandemi Covid-19. Jurnal Ilmiah Pendidikan Citra Bakti, 7(2), 125-136.

Srimulyani, V., \& Hermanto, Y. (2021). Online Learning During the Covid-19 Pandemic (Study at Several Schools and University in Indonesia). Jurnal Pendidikan Dan Pengajaran, 54(1). https://doi.org/10.23887/jpp.v54i1.29703.

Sugiyono. (2017). Metodologi Penelitian Pendidikan. Rineka Cipta.

Susilawati, S., Jamaluddin, J., \& Bachtiar, I. (2017). Pengaruh model pembelajaran berbasis masalah (pbm) berbantuan multimedia terhadap kemampuan berpikir kritis peserta didik kelas vii smp negeri 2 mataram ditinjau dari kemampuan akademik. Jurnal Pijar Mipa, 12(2), 64-70. https://doi.org/10.29303/jpm.v12i2.343.

Tegeh, I. M., \& Kirna, I. M. (2013). Pengembangan Bahan Ajar Metode Penelitian Pendidikan Dengan Addie Model. Jurnal Ikatan Alumni (IKA) Universitas Pendidikan Ganesha, 11(1). https://doi.org/10.23887/ika.v11i1.1145.

Uzun, A., Onur, A., \& Alabay, S. (2020). Students' views on database management systems course designed according to problem-based learning. International Journal of Evaluation and Research in Education, 9(1), 177-187. https://doi.org/10.11591/ijere.v9i1.20501.

Widyatmojo, G., \& Muhtadi, A. (2017). Pengembangan multimedia pembelajaran interaktif berbentuk game untuk menstimulasi aspek kognitif dan bahasa. Jurnal Inovasi Teknologi Pendidikan, 4(1), 38-49. https://doi.org/10.21831/jitp.v4i1.10194.

Zainiyati, H. S. (2017). Pengembangan media pembelajaran berbasis ICT: konsep dan aplikasi pada pembelajaran pendidikan agama islam. Kencana. 